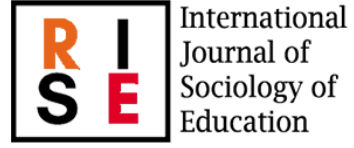

International Journal of Sociology of Education

\section{Hipatia Press}

www.hipatiapress.com

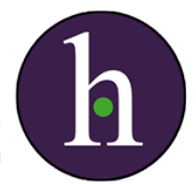

Instructions for authors, subscriptions and further details:

http://rise.hipatiapress.com

\title{
School Bullying. Teacher Interpretation Schemes and Conceptualizations
}

Panagiotis Efstratios Giavrimis ${ }^{1}$

1) University of the Aegean, Greece

Date of publication: October $25^{\text {th }}, 2020$

Edition period: October 2020-February 2021

To cite this article: Giavrimis, P.E. (2020). School Bullying. Teacher Interpretation Schemes and Conceptualizations, International Journal of Sociology of Education, 9(3), 325-347. http://doi.org/10.17583/rise.2020.5319

To link this article: http://dx.doi.org/10.17583/rise.2020.5319

\section{PLEASE SCROLL DOWN FOR ARTICLE}

The terms and conditions of use are related to the Open Journal System and to Creative Commons Attribution License (CC-BY) 


\section{School Bullying. Teacher Interpretation Schemes and Conceptualizations}

Panagiotis Efstratios Giavrimis

University of the Aegean

(Received: 30 March 2020; Accepted: 20 July 2020; Published: 25 October 2020)

\section{Abstract}

School bullying has been a perennial phenomenon and in recent years several studies have been conducted to investigate its consequences on those involved. School bullying is defined as a form of aggressive behavior in which one or more students engage in physical or psychological violence against a student repeatedly and for a long time, consciously, to cause physical or mental pain. The purpose of our research is to investigate the interpretations of Primary education teachers in the island of Lesvos. We use symbolic interaction to interpret the meanings that are produced, exchanged, and intertwined in the social context of school. In the present study, the qualitative method was used, its main feature being the interpretive and naturalistic approach to social reality. Teachers, as actors subject to a structurally defined environment of school bullying interpretations, have incomplete knowledge of its conceptualization, but 'established' criteria for discriminating and delimiting 'divergent' behavior, which can, however, raise problems in terms of categorization.

Keywords: school bullying, bully, victim, teachers 


\section{Acoso Escolar. Esquemas de Interpretación del Profesor y Conceptualizaciones}

Panagiotis Efstratios Giavrimis

University of the Aegean

(Recibido: 30 Marzo 2020; Aceptado: 20 Julio 2020; Publicado: 25

Octubre 2020)

\section{Resumen}

El acoso escolar ha sido un fenómeno perenne y en los últimos años se han realizado varios estudios para investigar sus consecuencias en los involucrados. El acoso escolar se define como una forma de comportamiento agresivo en el que uno o más estudiantes se involucran en violencia física o psicológica contra un estudiante repetidamente y durante mucho tiempo, conscientemente, para causar dolor físico o mental. El propósito de nuestra investigación es investigar las interpretaciones de los maestros de educación primaria en la isla de Lesbos. Utilizamos la interacción simbólica para interpretar los significados que se producen, intercambian y entrelazan en el contexto social de la escuela. En el presente estudio, se utilizó el método cualitativo, siendo su característica principal el enfoque interpretativo y naturalista de la realidad social. Los docentes, como actores sujetos a un entorno estructuralmente definido de interpretaciones de acoso escolar, tienen un conocimiento incompleto de su conceptualización, pero tienen criterios "establecidos" para discriminar y delimitar comportamientos "divergentes", que pueden, sin embargo, plantear problemas en términos de categorización.

Palabras clave: habilidades acoso escolar, acosador, víctima, profesorado 
chool bullying is defined as a form of aggressive behavior in which one or more students engage in physical or psychological violence against a student repeatedly and for a long time, consciously, to cause physical or mental pain. (Besag, 1989; Olweus, 2009). Typically, there is no challenge on the part of the student who accepts aggressive behavior, while the bully perceives himself / herself as stronger than the victim (Olweus, 1993; Swearer \& Doll, 2001). School bullying is characterized by the imbalance of physical or social power between the bully and the victim (Volk et al., 2014; Rigby, 2007). The difference between violent games and bullying is mainly the relationship that exists between the bully and the victim, but also in the intention of the communication (Bradshaw et al., 2009; Gladstone et al., 2006). The violence is brief, lasting on average 37 seconds and usually occurs at school. Most victims refuse to admit the existence of violence because they feel embarrassment, fear and shame, while only $25 \%$ of students report that teachers intervene in cases of violence (Bradshaw et al., 2007). A low-quality learning environment with violence creates an environment in which such situations can be more easily developed (Espelage \& Swearer, 2003; Rigby, 1999, 2001).

The forms of school bullying that emerge from a structuralist-positive theoretical analysis of the phenomenon are: Physical Bullying (Berry, 2018; Olweus 2009, p. 29), Verbal Bullying (Berry, 2018; Rigby, 2002; Olweus, 2009), Interpersonal Bullying (Crick et al., 2002, p. 99), Racist Bullying (Berry, 2018; Maniatis, 2010, pp. 126-127; Rigby, 2002, pp. 50-51)., Sexual Bullying (Berry, 2018; Rivers \& Duncan, 2012), and Cyberbullying (Berry, 2018; Kowalski et al., 2008; Pieschl et al., 2014).

Studies in different countries measure the percentage of students involved in such situations range from $2 \%$ to $16 \%$ (Nansel, 2003; Nansel et al., 2001; OECD, 2017; Olweus, 1993; Perry et al., 1988). There are, of course, studies in which the rates are almost double (World Health Organization, 2010). According to the PISA study (OECD, 2017), 6.7\% of the student population in Greece is bullied, with its main forms being mocking and spreading rumors. Furthermore, it appears that school performance in sciences, satisfaction with friendships, and a sense of injustice in teacher behavior play a role in victimization.

Victims and bullies are more likely to be boys who are bullied by boys (Andreou \& Bonoti, 2010; Kokkinos, \& Karagianni, 2017; Longobardi et al., 


\section{Giavrimis-School Bullying. Teacher Interpretation}

2017), while girls are bullied by boys and girls and are more likely to be bystanders (Andreou \& Bonoti, 2010; Kokkinos, \& Karagianni, 2017). Boys are more likely to be subjected to physical violence by their peers and girls to be victims of widespread sexual comments and social exclusion (Espelage \& Swearer, 2003; Hawker \& Boulton, 2000; Rigby, 1996, 2002). Also, the bullying and physical violence incidents decrease as the age increases (Byrne, 1994; Kokkinos, \& Karagianni, 2017).

The school bullying includes the bully, the victim, and the bystander (Cowie, \& Berdondini, 2001; Rose et al., 2011). Child victims lacking in emotional, social and academic field (poor performance), feel helpless, sometimes desperate, and mostly avoid school, reacting to the attack with crying, yelling, withdrawal, with poor communication and are physically weaker (Besag, 1989; Sullivan et al., 2004). In addition, people who are subjected to violence by others tend to have anxiety, lack of concentration, lack of interest and motivation, lack of confidence and self-control, and low self-esteem (Camodeca, \& Goossens, 2005; Juvonen et al., 2003; Macklem, 2003). Bystanders in bulling episodes are usually passively watching (Trach et al., 2010) or renforcing and are unlikely to help a victim (Kärnä et al., 2010; Thornberg, 2010).

As for bullies, Olweus distinguishes three types: aggressive, anxious, and passive (Olweus, 1993). Aggressive bully is more violent than the other two types, the anxious bully is anxious and aggressive (De Wet, 2005) and passive bully is a follower and support the bullies when the bulling episode begins (Aluede et al., 2008). Bullies are often impulsive, predominantly feel the needing to dominate others, lack empathy, have no anxiety and insecurity, have high self-esteem, perceive their actions as fair (Greenbaum, 1988; Olweus, 1991; Schwartz et al., 2001) and they are belonging in large groups or they are popular. Although, there are international surveys that report that they have low acceptance and low social skills (Varjas et al., 2008).

Risk factors associated with school bullying are interpersonal like lack of knowledge and awareness of significant others (Giannopoulou et al, 2010), parental maltreatment (Shields, \& Cicchetti, 2001) and parents violence (physical, verbal, symbolic), discipline (Bradshaw et al., 2009; Gladstone et al., 2006) or school environment (e.g. grade level, low academic achievement, unpopularity, social standing and dominance, school climate, teacher behaviour) and demographic characteristics like ethnicity, gender, social 
status (Swearer-Napolitano, 2011; Varjas et al., 2008) and intrapersonal characteristics (e.g hyperactivity-impulsiveness, low empathy, low selfesteem, depression, physical and biological features) (Jenkins et al., 2017; Farrington, \& Baldry, 2010, p. 1).

\section{Theoretical Framework}

Symbolic interactionism analyzes the interactions of social actors. This theory studies the ways in which individuals communicate, understand, and interpret the meanings that are produced, exchanged, and intertwined in the social context. Through the interaction of the actors at the micro level of the situation, individuals understand the intentions and motivations of the interacting subjects, elements that are embedded in the meanings that the subjects construct in their social action. Social reality is constructed through the negotiations of social actors (Blumer, 1986, 2004. Blumer \& Kuhn, 1991). Also, Zeegers and Barron (2015, p. 68) stress that: "Individuals construct their own social realities and perspectives of their world using responses from the environment and different sociocultural relationships with which they interact ..... the argument being that individuals do not react automatically to special stimuli ...." This process is dynamic and individuals handle, alter and reconstruct their perceptions and meanings through an interpretive process with the socio-cultural frame of school, local and global environment they confront.

Through subjective meanings, members of the educational community shape their interaction with other actors in the school environment, make evaluative judgments, and define their behavior. Teachers act towards sociocultural context on the basis of meanings they ascribe to their interactions with others within the school environment and social-cultural and educational structures (educational policy, legislations, teachers' role, school environment etc.) (Dennis, \& Martin, 2005; Sudtho et al., 2015; Teo, \& Osborne, 2012). Teachers' ratings and evaluative judgments are related to their interaction with students and the role they have in the school context, as well as to the generated inter-subjective perceptions (Ballantine, \& Spade, 2009). Teachers' perceptions affect the development of beliefs about social subjects or situations, while mediating in inter-individual communication and behavior (Blackledge, \& Hunt, 2019). Their judgments, ratings, and labels produce 


\section{Giavrimis-School Bullying. Teacher Interpretation}

serious consequences on students' learning and social inclusion (Blackledge, \& Hunt, 2019; Lamnias, 2002) and have negatives results, as cognitive segregation and stigma (Link et al., 2004).

In this context, the teacher, through his interpretations of school bullying, either consciously or unconsciously, they construct or reconstruct school reality and influence the identity formation of the victim and the bully and have a positive impact on discouraging school bullying. The manner in which teachers perceive and interpret the deviant behaviors of their students is an important factor in developing and implementing intervention programs for school bullying. (Veenstra et al.,2014).

\section{Teachers' Views on School Bullying}

In international and Greek research most studies explore school bullying in education through pupils' self-reports with quantitative methodological techniques. They emphasize on size, frequency (Bibou-Nakou et al., 2013; Sapouna, 2008), on its forms (Boulton et al., 2001; Houndoumadi \& Pateraki, 2001), on the factors that contribute to its occurrence (Smith et al., 2004), on the consequences, on its prevention and management strategies (Andreou et al., 2007). The views of teachers on bullying are not found in many published studies in peer-reviewed journals, even though there are several studies at the doctoral level. Even fewer are the qualitative research on this issue exists.

The literature points out that teachers recognize smaller number of cases, bullying in relation to their students (Boulton, 1997; Espelage et al., 2014), because they find it difficult to recognize them (DeOrnellas, \& Spurgin, 2017) or because they are indifferent (Craig, Bell, \& Leschied, 2011) or because their education has not been sufficient (Boulton, 1997; DeOrnellas, \& Spurgin, 2017; Gorsek, \& Cunningham, 2014). Teachers have a difficulty to distinguish between school bullying and peer conflict (Gorsek, \& Cunningham, 2014). There are, of course, sensitized teachers proactive trying to discourage bullying (Craig et al., 2011). Also, it has been found that the more empathy teachers have, the more they are involved in dealing with and recognizing the problem (Yoon, 2004). Bibou-Nakou et al. (2013) refers that teachers are less likely to be informed about school bullying incidents than friends or parents. Teachers differ in the way they approach different types of bullying (Stockdale et al., 2020). They refer more to externalizing problems 
(eg incidents of physical violence, aggression) (Atiş Akyol et al., 2018; DeOrnellas, \& Spurgin, 2017; Rekalidou, \& Karadimitriou, 2014), transferring causal factors to the family or student (DeOrnellas, \& Spurgin, 2017; Hepburn, 1997; Salgado et al., 2020) and highlight the educational policy shortcomings to address the school bullying phenomenon (Atiş Akyol et al., 2018).

In Greece, published research in peer-reviewed journals in relation to the views of primary school teachers in the phenomenon of school bullying is not enough (Assimopoulos et al., 2008; Assimopoulos et al., 2014; Glarentzou et al., 2009; Rekalidou, \& Karadimitriou, 2014). In regard to the views of primary teachers in Greece it is stressed that they: a) give a wide range of definitions of school bullying, b) give less weight to incidents of bullying deriving from their students, c) do not focus on the negative effects on mental health, but rather on physical health (Assimopoulos et al., 2008), (d) are frustrated with institutional support and inadequate education (Assimopoulos et al., 2008; Assimopoulos et al., 2014; Rekalidou, \& Karadimitriou, 2014), and (e) use the verbal bullying model as a way of dealing with it (Assimopoulos et al., 2008). Also, teachers consider that: a) extreme violence is not widespread in Greece, b) victims of school bullying are unable to defend themselves, c) use of new technologies in school bullying is not widespread (Glarentzou et al., 2009), d) assigning responsibility to parents (Glarentzou et al., 2009), e) tend to recognize only the incidents involving physical violence and serious consequences (Asimopoulos et al., 2014), f) mostly "talking privately with the child about his/her behavior" or their intervention is mainly disciplinary (Rekalidou, \& Karadimitriou, 2014, p. 786).

The purpose of our research is to investigate Primary education teachers' conceptualizations about school bullying in the island of Lesvos, using symbolic interaction as an analytic tool. Teachers are a significant intermediary factor in the phenomenon of school bullying and the identification of bullies and victims.

\section{Method}

In the present study, the qualitative method was used, as its main feature is the interpretive and naturalistic approach to social reality (Strauss, \& Corbin, 


\section{Giavrimis-School Bullying. Teacher Interpretation}

1990). The qualitative method emphasizes the subjective experience, signification and language code of the subjects, in order to highlight social phenomena (Kvale, 2008; Tsiolis, \& Siouti, 2013). In the present study, the qualitative method and the interpretive approach of symbolic interaction are used to analyze the views of teachers because: a) teachers are considered as an important mediation group in cognitive development and social inclusion of students (Veenstra et al., 2014), b) school bullying research usually analyzes quantitative data from student groups (Assimopoulos et al., 2014), c) the group of teachers and their views has not been sufficiently investigated with qualitative methods, d) The qualitative research material extracted from the micro-level of the interpretation of empirical data, produced by specific narratives is facilitated by the use of, the symbolic interaction theory, for the emergence of conceptual and semantic content, as expressed in individual daily experience. The focus is on the actions of individuals who are intersubjective and understandable, and d) in Greece there is very little qualitative research on views of primary school teachers on school bullying (e.g. Assimopoulos et al., 2008; Assimopoulos et al., 2014; Glarentzou et al., 2009). At the same time, the island of Lesvos was chosen because: a) the Greek regional policy applied in Greece is more general without giving particularities to the island regions, b) the islands of the North Aegean are the external borders of the European Union and gateways for migrants, (c) the island is characterized by socioeconomic and educational inequalities and d) teachers' views on school bullying have not been researched with the qualitative method.

\section{Participants}

The participants were 35 Primary education teachers on the island of Lesvos. Primary education was chosen because the phenomenon of school bullying originates and culminates in it (Artinopoulou, 2001), while teachers' interpretations, which are not frequently explored, are of major importance to the interaction among members of the educational community, but also the demarcation of the phenomenon. The age span of the teachers in our sample ranges between 35 and 55 years and their years of in-school service range between 12 and 30 years. Seventeen of the interviewees are women. 


\section{Research Tool}

The semi-structured interview was chosen as a research tool, as it provides "a weaker structure and greater freedom in both the delivery of questions and the variety of answers" (Rondos \& Papanis, 2006, p. 31), considering the fact that school bullying can be explored in the broader context of shadow education in Greece. An interview guide with twenty-six questions was constructed on the basis of the theoretical framework of school bullying (Besag, 1989; Nansel, 2003; Nansel et al., 2001; Olweus, 1993, 2009; Rigby, 2002; Swearer \& Doll, 2001) and globalized education framework (Gewirtz et al., 2009) along with the situation of school bullying in Greece (Bibou-Nakou et al., 2013; Sapouna, 2008). The interview guide had four main thematic axes relevant to: (a) Teachers' conceptualizations of the bullying phenomenon including questions on the definition, frequency and characteristics of it, b) Teachers' views on forms of bullying, including questions on their forms and characteristics c) Teachers' representations of the identity of the bully, including questions on the social and individual characteristics of the bullies, and (d) Teachers' representations of the identity of the victim, including questions about the social and individual characteristics of the victims.

\section{Procedure of Research and Data Analysis}

The data collection was conducted from September 2018 until January 2019. The interviews lasted about 40-45 minutes each and took place at the participants' physical space. During the communication with them, the respondents were informed about the nature and objectives of the research and the details of the interview were clarified so as to conclude the informed consent form. Participants were also assured about anonymity, confidentiality, and protection of their personal data, while the recording permission of the interview was secured.

The data were analyzed through the content analysis method, which attempts to reveal identifiable properties or situations that constitute the semantic determinants of the material for the purpose of drawing specific and valid conclusions. The sentence, referring to the subject under exploration, was used as a unit of analysis. The basic unit of analysis (word, concept) was chosen in relation to the key questions of our research, and when the analysis 


\section{Giavrimis-School Bullying. Teacher Interpretation}

unit (e.g. word) could only be interpreted in context (e.g. sentence), then this more extensive piece of content became the contextual recording unit (Kyriazis, 2002). The validity and effectiveness of the categorization were ensured through the application of the rules of objectivity, exhaustion, relevance and mutual exclusion (Bryman, 2017).

Our endeavor was to formulate categories and subcategories, so that in a dialectical way the transformation of reality is revealed through individuals' meanings and their perceptions of social reality. Thus, after having transcribed the narratives of the participants in our research, we proceeded to codify their responses by highlighting the categorizations of the reality that teachers give through their conceptualizations and analyzing the above based on the theoretical framework for school bulling without having forgotten that new categorizations of social reality may be emerging through the participants' sayings (Bryman, 2017; Tsiolis, 2014).

Research restrictions refer to the lacking generalization of findings and the limited location of research that is the island of Lesvos.

\section{Findings}

The empirical data were grouped into categories that highlighted the teachers' conceptualizations of the bullying phenomenon.

\section{Conceptualization of School Bullying.}

Our empirical data show that teachers did not define in a clear and comprehensive way the phenomenon of school bullying although they acknowledged the existence of bullying in their school unit and argued that it has increased in recent years. They did not define it in its true dimension. Specifically, they defined school bullying, either in a limited range of behaviors (rivalry, reaction, etc.), which are mostly common emotional reactions of school age, or by emphasizing some of its characteristics (organized pressure, long-lasting anger etc.). It also appears that in order to define it, they referred to age, frequency, causes, as well as the factors responsible for its occurrence. Two teachers only mentioned individual cases of simple friction and conflict among students: 
I4: "In Primary school, I think I told you that even before a child hits someone, it is something we can easily understand, either while oncall or in the classroom, so it is not so common. It happens, but without the intensity or the repetition to be considered school bullying".

I7: "I have seen more in the sense of e (.) friend groups. In this sense, I have seen it more. There are some kids who want to grab attention onto themselves in a class and along with other kids, they become a group. This group behaves negatively towards other groups and from there it all starts..."

I12: “... Yes, it is a phenomenon, which unfortunately has an increasing frequency nowadays. In my view, school bullying is an aggression that has duration and repetition. ...". I18: "I think both in the smaller and larger classes. That is, toddlers who come through a process of adapting perhaps even of delimitation of each child's individual space and older children when they are now in pre-adolescent situations". I20: "As organized pressure, exercised by older children to younger children, but as organized pressure, not isolated in a single instance".

\section{Types of school bullying.}

Participants referred to various forms of bullying several times, either directly, describing forms of bullying that took place at school, or indirectly through incidents that had to be managed.

The most prevalent forms of school bullying according to teachers' experiences are interpersonal: I2 "Most of what I see is that bullying exists and some kids are sharing secrets about personal issues .... With voices, hatred, complaints. He did it. That's it.", the sexual:

I8: “... It seemed aggressive, and I would say that it was sexual harassment, which was the move that some older students make. Sexually explicit gestures and comments seemed in style, but I found this out because I already was in the courtyard. When I was on call a bit further away, I couldn't detect it. I saw two kids that were on the same level, I didn't see movement, violence, nothing. There were gestures and specific movements. They were very well covered. If I 


\section{Giavrimis-School Bullying. Teacher Interpretation}

hadn't gone upstairs I wouldn't have found out ... That is one, two boys attacking the girls. They physically harass or they say something. That is, you see that they are making moves... and hit the girls in the chest at some point"

and verbal:

I11 "Taunting is another form ...something which is discovered in .... lesson. you see two or three laughs around ironically and tha ha ha- and somebody else is blushing. This is what you mostly encounter in the classroom. Also, some nicknames come out".

Some participants also reported physical bullying:

I4 "In Primary school, I think I told you that even before a child hits someone, it's something we can easily perceive, either in the on-call or in the classroom .... a simple push while running, can be the cause of a fight. Another reason is that someone deliberately put the child on a tricycle and threw it down or deliberately hit it. Why is there such behavior among some children?"

Although cyber-bullying is a phenomenon that has taken place in recent years, only a small number of respondents have reported it: I19 "We have come across cases of bullying via Facebook, or mobile phones.... It happens much more frequently in older ages". Also, few teachers referred to nonphysical bullying: I15 "One group of boys can start an activity and hang posters at school and the other group can take out posters, tear them down or write them down" and to racist bullying as a physical discrimination in terms of a student's weight-obesity: I10 "There are children who have a different body shape. Plump kids. The children are tough with each other and they do not take the problem seriously and make fun of it", or as a verbal expression for the national identity: I15 “.. formerly they were children from other countries. Mostly during previous years. Well, when you discussed it, they accepted it. I don't see that during the last three years".

\section{Characteristics of Bully.}

On the basis of our empirical data, the characteristics by which teachers 
construct the identity of the bully are grouped as follows: Physical and social characteristics, gender, school performance and ethnicity. Teachers' views converge regarding the role of the bully in various bullying incidents in the sense that bullies are usually large in body shape. They argue that bullies' physical superiority help them dominate the weakest students: I12 "a welldeveloped and well-trained child is likely to do martial arts because this is the way parents are at this age... and they are children who generally believe that they have a way of dominating others and with physical displacement".

According to the teachers' views, boys are more likely to be bullies, mainly in cases of physical bullying. Girls tend to use indirect forms of bullying that are not easily understood when they assume the role of the offender: slander, rumors, gossip: I16 "Yes. Mostly done by boys. Boys are the most intimidating. Girls are stealthier. They will not be intimidated immediately; they will just spread some news at some point."

Teachers generally describe the bully as a social and highly popular child, who, either by his physical superiority or by his leading personality dominates his peers in an attempt to make his presence felt, without being aware of his intention to do harm. They call him both "sneaky" and "envious". I19: "The bully is a child who is extroverted, possibly social, and particularly socially developed, ... the way they push, disturb, drag, talk, the possessive way towards other children is that in my opinion they are made to be ...". I5: "He wants to dominate in the class and because we are talking about sixth grade, things are a bit strange in sixth grade ..."

I8: "He was a popular kid. He made friends. This year especially he was somehow the leader. He was welcomed by girls and boys. In fact, when I did a sociogram... he was one of the most popular. Not a child isolated, observed or anything else..."

I14: "Because it shows a sneaky, lascivious person, it is no longer the child who will react..."

Teachers' views of the bully's school performance vary, in the sense that some teachers argue that bullies are smart and good students, while others think they may be average students: 


\section{Giavrimis-School Bullying. Teacher Interpretation}

I3 "Very good students and from very good families ...), or middle schooler / teacher: He was a middle schooler. He was neither an excellent student, nor, of course, indifferent. Always doing his homework. Studying, not perfectly, but still studying. ...... With the data of the old times between 8 and 9". The fact that teachers associate students' school performance with their parents' marital status is also very interesting: I11 "I'll tell you about a case of psychological intimidation between two girls with a difficult family background .... both smart kids and good students".

The perception of national background ascribed to the identity of the bully cannot be generalized, as it is reported only by one. I18 teacher: “... from other countries that are leaders or leaders in that sense..."

\section{Characteristics of Victim}

The categories that emerged from the teachers' views about the victim's identity are: Physical appearance, social and individual characteristics of the victim, gender, social class and nationality of the victim. The most obvious explanation that children, who differ in appearance (too weak or too fat), are more easily bullied in school (Rigby, 2002; Voss \& Mulligan, 2000) seems to be adopted by the majority of teachers: 17 " ... related to their weight, fat kids .... The target group is the kids who have a different body shape. The fat kids." While other interviewees seem to endorse this view, they point out that children can also become victims with no bodily deviations", I3 "It is not necessary that they are physically smaller or anything else. They are children who compete, that is, at the same level.... I have found it in approximately peer children. There was a huge physical difference".

From the teachers' point of view, the role of the victim can be attributed to both girls and boys. However, there is significant research interest in the fact that the gender of teachers influences their attitude since women present the girls as victims.

I14: "Victims are usually girls, and that is why girls have grown up with this, with some stereotypes that we have not overcome as much as we would like to be seen as a progressive and modern society. There are stereotypes that point to a compliant, modest and low-key woman, so whether we like it or not, it still goes to the girls" 
while male teachers attribute this role to boys: 19 "The gender of the victims is boys. Boys usually."

Teachers' views on the identity of the victim converge since they present the victim as a subordinate, socially isolated, low self-esteem person who usually assumes responsibility for his or her own victimization:

I2: "The victim is a low-profile kid, without much self-esteem... particularly objectionable as a result of being manipulated by other children ...... they are particularly objectionable and play the role of victim .... They think they deserve this or that others have made them believe it. They are introverted children, they are low-key children, they may be very good or very bad students".

Discriminating students according to their social class is a possible cause of victimization: I11 "Mostly, they are children who may belong to another social class".

As regards the victims' country of origin, teachers argue that migrant students used to be an easy target group some years ago, since foreign students' adaptation to Greek schools was difficult. Nowadays, however, foreign students are not so marginalized. Therefore, all students are a target group when it comes to bullying: I15 "They used to be children from other countries".

The teachers' reasoning about the identity of the bully is plain, very cautious, with no particular aggressive identifications and with a disposition to justify such behavior, a fact that is not observed in the victim's description.

\section{Discussion}

The purpose of this study was to explore Primary school teachers' interpretations about school bullying in relation to the identity of the victim and the victimizer in the island of Lesvos. The results of the research revealed that the teachers - participants in the study: a) recognize that school bullying takes place in their school, but their conceptualizations about the definition of bullying are lacking, while focusing on its individual characteristics, causes and the factors that contribute to its occurrence, (b) highlight the common 


\section{Giavrimis-School Bullying. Teacher Interpretation}

emotional reactions, the intolerance to actions and the repetitive nature of the phenomenon as distinctive features of divergence from the typical student behavior. The fact that two teachers argue about individual incidents of mere friction and conflict among students highlights the relevance of the interpretation of school bullying, c) refer to most forms of school bullying illustrated in the literature (interpersonal bullying, sexual bullying, verbal bullying, cyber-bullying, physical bullying, non-physical bullying, racist bullying) (Crick et al., 2002; Kowalski et al., 2008; Maniatis, 2010; Olweus, 2009; Rigby, 2002; Rivers \& Duncan, 2012) and d) they underline that the integration of immigrants into the school does not seem to differentiate the phenomena of school bullying, because probably the natives, due to their earlier interaction with immigrants, have adapted appropriately to the new social reality of the island. Despite the delimitations of the scientific community regarding school bullying, namely the social externalized legitimized reality, teachers' conceptualizations of this phenomenon are presented with shortcomings and ambiguities. It appears that the social representations within the group of teachers clarify more the morphological and epidemiological characteristics of the phenomenon and less its conceptual entity. The gap between the science-positive reality and the individual teachers' interpretations originates from the inadequate apparatus of education and training in treatment of behavioral problems (Athanasiades, \& Psalti, 2011). Teacher education in Greece is unsystematic and incomplete (Rekalidou, \& Karadimitriou, 2014), while the definition of school bullying due to its general ambiguity in the global community, confuses teachers, who need to distinguish school bullying and violent behavior (Gorsek, \& Cunningham, 2014).

All educators define the bully as a person holding a dominant position of power or authority over the victim, at the same time, popular, sociable, with leadership tendencies and physical superiority. Yet, "sneaky" and "downright" trying to harm, but also with differentiated performance. Also, they referred to the difficult family background of bullies. Boy-bullies cause incidents of physical bullying and girl-bullies mostly focus on indirect bullying. As regards, the identity of the victim, they provide detailed descriptions in which the victim is presented as an isolated, compliant, guilty child with low selfesteem and uncommon appearance. In addition, teachers referred to social class as a possible cause of victimization. The above are in line with the 
findings of international and Greek literature (Andreou \& Bonoti, 2010; Besag, 1989; Boulton \& et al., 2001; Gotovos, 1996; Kokkinos, \& Karagianni, 2017; Longobardi et al., 2017; Olweus, 1993, 2009; Rigby, 1996; Sapouna, 2008; Sullivan et al., 2004; Swearer \& Doll, 2001). Teachers shape their typologies through social interaction with students, distinguishing between the characteristics of the victimizer and the victim and signifying the primary importance of the individual's social status, appearance, and interpersonal characteristics (Lamnias, 2002). These elements are social concepts and their disclosure and legitimation form the structural - causal factors that shape the identity of the bully and the victim. These well-established teachers' interpretative schemas can be linked to social stigmatization, labeling, and student categorization (Link et al., 2004). Their reproduction can influence the interpretation of goals and intentions in teacher - student interactions, as well as their roles, but they can also shape the context of their interpretative and reflective actions.

In conclusion, teachers, as actors interpreted school bullying through their interaction with school community members and with the socio-cultural frame of the environment. They have incomplete knowledge of its conceptualization, but 'established' criteria for discriminating and delimiting 'divergent' behavior, which can, however, raise problems in terms of categorization. The wider environment that came into existence on the island of Lesvos in recent years, with the flow of migration, does not seem to affect the teachers' conceptualizations. At the same time, there is a need for better teacher training in school bullying. It is necessary for teachers to be educated and trained on issues related to behavioral problems, the relativization of objective theory, the recognition of the causes of the produced and reproduced cognitive patterns, and the emergence of individuals' interpretations as the building blocks of boundaries and interaction in the school context.

\section{References}

Aluede, O., Adeleke, F., Omoike, D., \& Afen-Akpaida, J. (2008). A review of the extent, nature, characteristics and effects of bullying behaviour in schools. Journal of Instructional Psychology, 35(2), 151-158.

Andreou, E., \& Bonoti, F. (2010). Children's bullying experiences expressed through drawings and self-reports. School Psychology International, 


\section{1, 164-177. https://doi.org/10.1177/0143034309352421}

Artinopoulou, B. (2001). School violence. Research and policies in Europe.

Athens: Metaxmio.

Assimopoulos, C., Bibou-Nakou, I., Hatzipemou, T., Soumaki, E., \& Tsiantis, J. (2014). An investigation into students' and teachers' knowledge, attitudes and beliefs about bullying in Greek primary schools. International Journal of Mental Health Promotion, 16(1), 4252.

Assimopoulos, Ch., Chatzipemou, Th., Soumaki E., Diareme, S., Giannakopoulou, D., \& Tsiantis, I. (2008): The phenomenon of bullying in primary school: Opinions of students, views of teachers.

Child and Adolescent, 10, 97-110.

Athanasiades, C., \& Psalti, A. (2011). Secondary education teachers' knowledge and views about school bullying. Hellenic Journal of Psychology, 8, 66-95. https://pseve.org/wpcontent/uploads/2018/03/Volume08_Issue1_Athanasiades.pdf Atiş Akyol, N. E. V. R. A., Yildiz, C., \& Akman, B. (2018). Teachers' Views of Peer Bullying and Their Coping Strategies with Bullying. Journal of education, 33(2), 439-459.

Ballantine, J. H. \& Spade, J. Z. (2008). Schools and society: A sociological approach to education. Wadsworth.

Berry, K. (2018). LGBT bullying in school: A troubling relational story. Communication Education, 67 (4), 502-513.

Besag, V. E. (1989). Bullies and Victims in Schools. Open University Press. Bibou-Nakou, I., Asimopoulos, C., Hatzipemou, T., Soumaki, E., \& Tsiantis, J. (2013). Bullying in Greek secondary schools: prevalence and profile of bullying practices. International Journal of Mental Health Promotion, 16(1), 3-18.

http://dx.doi.org/10.1080/14623730.2013.857824

Blackledge, D., \& Hunt, B. (2019). Sociological interpretations of education. Routledge.

Blumer, H. \& Kuhn, M. (1991). Symbolic Interactionism. In J.H. Turner. (Ed.) The structure of sociological theory (pp. 291-409). Belmont, CA: Wadsworth.

Blumer, H. (1986[1969]). Symbolic Interactionism. Perspective and method. Prentice Hall. 
Blumer, H. (2004). George Herbert Mead and human conduct (Ed. and Intr.by T. Morrione). Altamira Press.

Boulton, J. M., Kalellou, I., Laniti, I., Manousou, B., \& Lemoni, O. (2001). Aggression and victimization among the students of the Greek Primary Schools. Psychology, 8(1), 12-29.

Boulton, M. J. (1997). Teachers' views on bullying: Definitions, attitudes and ability to cope. British Journal of Educational Psychology, 67(2), 223-233.

Bradshaw, C. P., Sawyer, A. L., \& O'Brennan, L. M. (2007). Bullying and peer victimization at school: Perceptual differences between students and school staff. School Psychology Review, 36, 361-382.

Bradshaw, C. P., Sawyer, A. L., \& O'Brennan, L. M. (2009). A social disorganization perspective on bullying-related attitudes and behaviors: The influence of school context. American Journal of Community Psychology, 43(3-4), 204-220.

https://doi.org/10.1007/s10464-009-9240-1

Bryman, A. (2017). Social research methods (A. Aidinis, Eds., P.

Sakelarariou, Trans.). Athens: Gutenberg.

Byrne, B. J. (1994). Bullies and victims in a school setting with reference to some Dublin schools. The Irish Journal of Psychology, 15(4), 574586.

Camodeca, M., \& Goossens, F. A. (2005). Aggression, social cognitions, anger and sadness in bullies and victims. Journal of Child Psychology and Psychiatry, 46, 186-197. https://doi.org/10.1111/j.14697610.2004.00347.x

Cowie, H., \& Berdondini, L. (2001). Children's reactions to cooperative group work: a strategy for enhancing peer relationships among bullies, victims and bystanders. Learning and instruction, 11(6), 517-530.

Craig, K., Bell, D., \& Leschied, A. (2011). Pre-service Teachers' Knowledge and Attitudes Regarding School-Based Bullying. Canadian Journal of Education, 34(2), 21-33.

Crick, N.R., Casas, J.F., \& Nelson, D.A. (2002). Toward a more comprehensive understanding of peer maltreatment: Studies of relational victimization. Current Directions in the Psychological Sciences, 11, 98-101. https://doi.org/10.1111/1467-8721.00177

De Wet, C. (2005). The nature and extent of bullying in Free State secondary 
schools. South African Journal of Education, 25(2), 82-88.

Dennis, A., \& Martin, P. J. (2005). Symbolic interactionism and the concept of power. The British journal of sociology, 56(2), 191-213.

DeOrnellas, K., \& Spurgin, A. (2017). Teachers' Perspectives on Bullying.

Bullying in School, 49-68. http://doi.org/10.1057/978-1-137-59298-

93

Espelage, D. \& Swearer, S. M. (2003). Bullying in American schools: A social-ecological perspective on prevention and intervention.

Mahweh, NJ: Earlbaum.

Espelage, D. L., Polanin, J. R., \& Low, S. K. (2014). Teacher and staff perceptions of school environment as predictors of student aggression, victimization, and willingness to intervene in bullying situations.

School Psychology Quarterly, 29(3), 287-305.

https://doi.org/10.1037/spq0000072

Farrington, D. P., \& Baldry, A. (2010). Individual risk factors for school bullying. Journal of aggression, conflict and peace research, 2(1), 416.

Gewirtz, S., Mahony, P., Hextall, I., \& Cribb, A. (Eds.). (2009). Changing teacher professionalism. International trends, challenges and ways forward. London: Routledge. https://doi.org/10.4324/9780203887264 Gladstone, G. L., Parker, G. B., \& Malhi, G. S. (2006). Do bullied children become anxious and depressed adults? A cross-sectional investigation of the correlates of bullying and anxious depression. Journal of Nervous and Mental Disease, 194, 201-208.

https://doi.org/10.1097/01.nmd.0000202491.99719.c3

Glarentzou, E., Karagianni, L., Kotalidis, G., Tzelfe-Anesti, S., \& Charamis, P. (2009). School groups of abuse of pupils/ students. Indications of a probe research approach. http://olme-

attik.att.sch.gr/files/article/omadesviaskemete.pdf

Gorsek, A. K., \& Cunningham, M. M. (2014). A review of teachers' perceptions and training regarding school bullying. Pure insights, 3(1). https://digitalcommons.wou.edu/pure/vol3/iss 1/6/.

Gotovos, A. E. (1996). Youth and Social Change. Values, Experiences and Perspectives. Athens: Gutenberg.

Greenbaum, S. (1988). School bully \& victimization. Malibu, CA: National School Safety Center. 
Hawker, D.S.J., \& Boulton, M.J. (2000). Twenty years' research on peer victimization and psychosocial maladjustment: A meta-analytic review of cross-sectional studies. Journal of Child Psychology and Psychiatry, 41, 441-455. https://doi.org/10.1111/1469-7610.00629

Hepburn, A. (1997). Teachers and secondary school bullying: A postmodern discourse analysis. Discourse \& society, 8(1), 27-48.

Houndoumadi, A., \& Pateraki, L. (2001). Bullying and bullies in Greek Elementary Schools: Pupils' attitudes and teachers'/parents' awareness. Educational Review, 53(1), 19-26. https://doi.org/10.1080/00131910120033619

Jenkins, L. N., Demaray, M. K., \& Tennant, J. (2017). Social, emotional, and cognitive factors associated with bullying. School psychology review, 46(1), 42-64.

Juvonen, J, Graham S, \& Schuster MA. (2003). Bullying among young adolescents: The strong, the weak, and the troubled. Pediatrics, 112(6), 1231-1237. https://doi.org/10.1542/peds.112.6.1231

Kärnä, A., Voeten, M., Poskiparta, E., \& Salmivalli, C. (2010). Vulnerable children in varying classroom contexts: Bystanders' behaviors moderate the effects of risk factors on victimization. Merrill-Palmer Quarterly, 56(3), 261-282.

Kokkinos, K., \& Karagianni, K. (2017). Bullying and victimisation: Bibliographic review of research findings from the Greek area.

Preschool and Primary Education, 5(1), 2-45.

Kowalski, M. R., Limber, P. S., \& Agatston, W. P. (2008). Cyber Bullying. Bullying in the Digital Age. British Library: Blackwell.

Kvale, S. (2008). Doing interviews. Sage.

Kyriazis, N. (2002). Sociological research, critical overview of methods and techniques. Athens: Ellinika Grammat.

Lamnias, K. (2002). Sociological theory and education: Distinct approaches. Athens: Metaixmio.

Link, B. G., Yang, L. H., Phelan, J. C., \& Collins, P. Y. (2004). Measuring mental illness stigma. Schizophrenia Bulletin, 30(3), 511-541. https://doi.org/10.1093/oxfordjournals.schbul.a007098

Longobardi, C., Prino, L. E., Fabris, M. A., \& Settanni, M. (2017). Violence in school: An investigation of physical, psychological, and sexual victimization reported by Italian adolescents. Journal of School 
Violence, 18(1), 49-61.

https://doi.org/10.1080/15388220.2017.1387128

Macklem, G. L. (2003). Bullying and teasing: Social power in children's groups. New York: Kluwer Academic/Plenum.

Maniatis, П. (2010). School violence and diversity in Greece: The necessity of intercultural education. Mentoras, 12, 126-127.

Nansel, T. R., Overpeck, M., Pilla, R. S., Ruan, W. J., Simons-Morton, B., \& Scheidt, P. (2001). Bullying behaviors among US youth: Prevalence and associations with psychosocial adjustment. Journal of the American Medical Association, 285, 2094-2100.

https://doi.org/10.1001/jama.285.16.2094

Nansel, W.E. (2003). The Genetics of deafness. Mental retardation \& developmental disabilities, 9, 109-119.

https://doi.org/10.1002/mrdd.10067

OECD (2017). PISA 2015 Results (Volume III): Students' Well-Being. Paris: PISA, OECD Publishing. https://doi.org/10.1787/9789264273856-en.

Olweus, D. (1993) Bullying at school: What we know and what we can do. Cambridge: Blackwell.

Olweus, D. (1993). Bullying at school: What we know and what we can do (understanding children's worlds). Malden, MA: Blackwell.

Olweus, D. (2009). Bullying and Violence at school. What we know and what we can do (G. Tsiantis, Ed.). Athens: EPSYPE.

Perry, D. G., Kusel, S. J., \& Perry, L. C. (1988). Victims of peer aggression. Developmental Psychology, 24, 807-814.

https://doi.org/10.1037/0012-1649.24.6.807

Pieschl, S., Kuhlmann, C., \& Porsch, T. (2014). Beware of Publicity! Perceived Distress of Negative Cyber Incidents and Implications for Defining Cyberbullying. Journal of School Violence, 14(1), 111-132. https://doi.org/10.1080/15388220.2014.971363

Rekalidou, G., \& Karadimitriou, K. (2014). Practices of early childhood teachers in Greece for managing behavior problems: A preliminary study. Procedia-Social and Behavioral Sciences, 152, 784-789.

Rigby, K. (1996). Peer victimization and the structure of primary and secondary schooling. Primary Focus, 10(7), 4-5.

Rigby, K. (1999). Bullying in schools: And what to do about it. Melbourne, Australia: ACER. 
Rigby, K. (2001). Health consequences of bullying and its prevention in schools. In J. Juvonen \& S. Graham (Eds.), Peer harassment in school: The plight of the vulnerable and victimized (pp. 310-331). New York: Guilford Press.

Rigby, K. (2002). School bulling. Contemporary views (A. Giovazolias, Ed., B. Dobola, Trans.). Athens: Topos.

Rigby, K. (2007). Bullying in Schools: And What to Do about It. Melbourne, AU: Australian Council for Education Research.

Rivers, I., \& Duncan, N. (Eds.) (2012). Bullying: Experiences and discourses of sexuality and gender. London: Routledge.

Rontos, K., \& Papanis, E. (2006). Statistical research. Methods and applications. Athens: Sideris.

Rose, C. A., Monda-Amaya, L. E., \& Espelage, D. L. (2011). Bullying perpetration and victimization in special education: A review of the literature. Remedial and special education, 32(2), 114-130.

Salgado, F. S, Oliveira, W. A, Silva, J. L, Pereira, B. O, Silva, M. A. I. \& Lourenço, L. M. (2020). Bullying in school environment: the educators' understanding. Journal of Human Growth and Development, 30(1), 58-64.

Sapouna, M. (2008). Bullying in Greek primary and secondary schools. School Psychology International, 29(2), 199-213. https://doi.org/10.1177/0143034308090060

Schwandt, T.A. (1994). Constructivist, interpretivist approaches to human inquiry. In N.K .Denzin, \& Y.S. Lincoln (Eds), Handbook of qualitative research (pp. 118-138). Thousand Oaks: Sage.

Schwartz, D., Proctor, L. J., \& Chien, D. H. (2001). The aggressive victim of bullying: Emotional and behavioral dysregulation as a pathway to victimization by peers. In J. Juvonen \& S. Graham (Eds.), Peer harassment in school: The plight of the vulnerable and victimized (pp. 147-174). New York: Guilford Press.

Shields, A., \& Cicchetti, D. (2001). Parental maltreatment and emotion dysregulation as risk factors for bullying and victimization in middle childhood. Journal of clinical child psychology, 30(3), 349-363.

Smith, P., Nika, V., \& Papasideri, M. (2004). Bullying and violence in schools: An international perspective and findings in Greece. Psychology, 11(2), 184-203. 
Stockdale, M.S., Hangaduambo, S., Duys, D., Larson, K., Sarvela, P.D. (2002). Rural elementary students', parents', and teachers' perceptions of bullying. American Journal of Health Behaviour; 26(4), 266 -277.

Strauss, A., \& Corbin, J. (1990). Basics of qualitative research. Sage publications.

Sudtho, J., Singhasiri, W., \& Jimarkon, P. (2015). Using symbolic interactionism to investigate teachers' professional identity. Pertanika Journal of Social Sciences and Humanities, 23(4), 1153-1166.

Sullivan, K., Clearly, M., \& Sullivan, G. (2004). Bullying in secondary schools: What it looks like and how to manage it. London: Corwin Press.

Swearer, S. M., \& Doll, B. (2001). Bullying in schools: An ecological framework. In R. A. Geffner, M. Loring, \& C. Young (Eds.), Bullying behavior: Current issues, research and interventions (pp. 7-23).

Binghamton, NY: Haworth Press.

Swearer-Napolitano, S. M. (2011). Risk factors for and outcomes of bullying and victimization (Paper 132). Educational Psychology Papers and Publications. Retrieved from http://digitalcommons.unl.edu/edpsychpapers/132

Teo, T. W., \& Osborne, M. (2012). Using symbolic interactionism to analyze a specialized STEM high school teacher's experience in curriculum reform. Cultural Studies of Science Education, 7(3), 541567.

Thornberg, R. (2010). A Student in Distress: Moral Frames and Bystander Behavior in School. The Elementary School Journal, 110(4), 585608. http://doi.org/10.1086/651197

Trach, J., Hymel, S., Waterhouse, T., \& Neale, K. (2010). Bystander responses to school bullying: A cross-sectional investigation of grade and sex differences. Canadian journal of school psychology, 25(1), 114-130.

Tsiolis, G. \& Siouti, I. (Eds.) (2013). Biographical (re)constructions in late modernity. Theoretical and methodological issues of biographical research in social sciences. Athens: Nisos.

Tsiolis, G. (2014). Methods and techniques of analysis in qualitative social research. Athens: Kritiki.

Varjas, K., Meyers, J., Bellmoff, L., Lopp, E., Birckbichler, L., \& Marshall, 
M. (2008). Missing voices: Fourth through eighth grade urban students' perceptions of bullying. Journal of School Violence, 7(4), 97-118.

Veenstra, R., Lindenberg, S., Huitsing, G., Sainio, M., \& Salmivalli, C. (2014). The role of teachers in bullying: The relation between antibullying attitudes, efficacy, and efforts to reduce bullying. Journal of Educational Psychology, 106(4), 1135-1143. https://doi.org/10.1037/a0036110

Volk, A. A., Dane, A. V., \& Marini, Z. A. (2014). What is bullying? A theoretical redefinition. Developmental Review, 34 (4), 327-343.

Voss, LD., \& Mulligan, J. (2000). Bullying in school: Are short pupils at risk? Questionnaire study in a cohort. British Medical Journal, 320(7235), 612-613. https://doi.org/10.1136/bmj.320.7235.612

World Health Organization (2010). Health behavior in school aged children (HBSC) study: International report from the 2009-2010 survey. Regional Office for Europe: WHO.

Yoon, J. S. (2004). Predicting teacher interventions in bullying situations. Education and treatment of children, 27(1), 37-45.

Zeegers, M., \& Barron, D. (2015). Milestone moments in getting your PhD in qualitative research. Amsterdam: Chandos Publishing.

Panagiotis Efstratios Giavrimis is a professor at the University of the Aegean, Greece

Contact Address: giavrimis@soc.aegean.gr 